\title{
Energy Balance and Green House Gas Emisson on Smallholder Java Coffee Production at Slopes ljen Raung Plateau of Indonesia
}

\author{
Soni Sisbudi Harsono ${ }^{1 *}$, Robertoes Koekoeh Koentjoro Wibowo², Edy Supriyanto ${ }^{3}$ \\ 1 Department of Agricultural Enginering, Faculty of Agricultural Technology, University of Jember, Jalan \\ Kalimantan 1 Jember, East Java Province, Indonesia \\ 2 Department of Mechanical Engineering Faculty of Engineering, University of Jember, Jalan Kalimantan 93 \\ Jember, East Java Province, Indonesia \\ 3 Department of Physics, Faculty of Mathematics and Natural Sciences, University of Jember, Jalan Kalimantan \\ 37 Jember, East Java Province, Indonesia \\ * Corresponding author's e-mail: s_harsono@unej.ac.id
}

\begin{abstract}
Coffee production has been a major source of income in Indonesia since the early twentieth century. This study aimed to estimate the energy balances and determine the environmental impact of Robusta and Arabica coffee production as well as identify the measures to increase the efficiency of Robusta and Arabica yield using the life cycle assessment (LCA) method. The potential adverse impacts of processing ground coffee manifest themselves in the forms of greenhouse gas (GHG) emissions, acidification, as well as water and environmental pollution due to solid and liquid waste disposal. The total GHG emissions for Arabica coffee processing is $1,804 \mathrm{t} \mathrm{CO}_{2}$-eq year ${ }^{-1}$ while for Robusta, it is $1,356 \mathrm{t} \mathrm{CO}_{2}$-eq year ${ }^{-1}$. The total acidification potential for Arabica coffee processing can be given by $8,013 \mathrm{~kg} \mathrm{NO}_{2}$ eq year ${ }^{-1}$ and $10,663 \mathrm{~kg} \mathrm{SO}_{2}$-eq year ${ }^{-1}$, while for Robusta coffee processing, the potential for acidification is represented by $60.97 \mathrm{~kg} \mathrm{NO}_{2}$-eq year ${ }^{-1}$ and $79.58 \mathrm{~kg} \mathrm{SO}_{2}$ eq year ${ }^{-1}$, and the potential GHG per unit weight of Arabica and Robusta ground coffee processing were $98.7 \mathrm{CO}_{2}$-eq $\mathrm{kg}^{-1}$ and Robusta $119.6 \mathrm{CO}_{2}$-eq $\mathrm{kg}^{-1}$, respectively. The potential measures to mitigate this include replacing gasoline with biofuel, utilising liquid waste with chemical processing, and solid wastes of coffee production, such as brickquetess and bio-pellets for renewable energy.
\end{abstract}

Keywords: Arabica and Robusta, greenhouse gas emission, acidification, renewable energy

\section{INTRODUCTION}

Coffee is one of Indonesia's foreign exchange earners and plays an important role in the development of the plantation industry. Over a period of 20 years, the area and production of coffee plantations in Indonesia, especially smallholder coffee plantations, has experienced very significant developments. In the 21 st century, the area and production of smallholder coffee plantations amounted to 663 thousand hectares and 276 thousand tons, respectively, and in 2009 there was an increase in the area and production area of 1,241 million hectares and 676 thousand tons, respectively (USDA, 2019; Vera-Acepedo, 2016). In
2010, the area of coffee plantations in Indonesia reached 1,210,000 hectares with a production of 686,920 tons, exports of 433,600 tons with a value of 814.3 million USD. Meanwhile in 2011, the mean coffee area amounted to 1,677,000 hectares, coffee with a production of 633,990 tons, exports 387,870 tons with a value of $1,198.9$ million USD. Data from the Ministry of Environment of Indonesia (2012) shown that the growth average of coffee area increased by $0,25 \%$; total production by $0.2 \%$; export volume also increase by $13.31 \%$ and export value Coffee by $12.61 \%$ in period of year 2007 until 2010. This data also stated that in year 2012, total areas of coffee plantation reached 13,510 ha which spread-out across provinces of 
Aceh, North Sumatra, Bali, East Nusa Tenggara and South Sulawesi.

In addition to this program, in the same year, the Arabica coffee area was expanded by 1,650 hectares and in the case of the Robusta coffee, it reached 2,950 hectares. In 2012, the area of coffee plantations was targeted to reach $1,354,000$ ha with a production value and productivity of 733,000 tons and $743 \mathrm{~kg}$ per hectare, respectively (Azwar, 2012; Ibnu et al., 2018).

Eighty-two percent of Indonesia's coffee plantation area is dominated by the Robusta coffee, while the remaining $18 \%$ is the Arabica coffee. The price of the Robusta coffee in the domestic and international markets is cheaper when compared to the Arabica coffee, although the volume of Arabica in the world market reaches $70 \%$, while the Robusta coffee is only $30 \%$. Converse$1 y$, in Indonesia, the Robusta coffee production reaches $80 \%$, while Arabica is only $20 \%$ of total coffee production (Kiyingi and Gwali, 2012). Increasing the area and production of Indonesian coffee, which is dominated by the Robusta coffee from smallholder plantations and world market opportunities, is a great potential for improving the welfare of Indonesian farmers.

Coffee is one of the plantation commodities which is included in the strategic commodity category. This commodity is important, because it meets the domestic needs and serves as an export earner for foreign exchange country. Coffee is the fourth largest foreign exchange earner for Indonesia after palm oil, rubber and cocoa in the agricultural commodity group. On the basis on data from the Indonesian Central Bureau of Statistics/BPS (2017), Indonesia's coffee exports in 2017 reached 467,800 tons with a value of US $\$ 1,187,157$. According to the Agency Central Statistics, in 2017 the area of coffee plantations in Indonesia reached $1,253,796$ ha. Total production of Indonesian coffee in 2017 reached 668,677 tons.

One of the largest areas of land that contributes to coffee production in Indonesia is East Java Province. East Java Province Including as one of the provinces in Indonesia that always has dynamic regional economic development. The regency or city certainly has its complexities and separate problems, such as regional potential which is supported by several factors and subsectors which can affect the performance of each district or city economy. East Java is an area where the smallholder coffee plantations are spread over several regencies such as Trenggalek, Blitar,
Kediri, Malang, Pasuruan, Jember, Bondowoso, and Situbondo that has the potential to be planted with coffee in the form of the Robusta coffee and Arabica coffee. East Java has several coffee production center areas with their respective product characteristics. The coffee products of each region are capable of penetrating the international market. One of the potential areas as a coffee producer in East Java which also contributes The largest coffee production is Bondowoso Regency. Coffee is a superior commodity in Bondowoso Regency. Almost $48 \%$ of the area of Bondowoso Regency is hilly with an altitude of $800-1200$ meters above sea level which is very potential to be developed as a coffee plantation.

The people in Bondowoso have received support from the government so that they are able to penetrate the European exports market. Bondowoso Regency is one of the coffee growing centers in East Java produces coffee with a distinctive taste known as "Java Coffee". It has a rich blend of aroma and herbal flavor to the aftertaste, so coffee lovers adore it around the world. The area coffee cultivated in Bondowoso Regency is 13,534.76 hectares with a result of 2,712.94 Oce $\mathrm{t}^{-1}$, managed by 44 farmer groups with IDG number 000023 , known as the "Java Coffee" brand Ijen Raung, produced from the Arabica coffee plants grown in the Ijen Plateau and Raung at an altitude of 900 meter above sea level (Fatmawati, 2018).

One of the largest coffee-producing districts in Bondowoso Regency is the District Sumber Wringin. This District is one of the 4 sub-districts that are being developed to become an agropolitan area for coffee commodities apart from the Sempol, Sukosari, Tlogosari districts determined by the Regent of Bondowoso in accordance with Regent Regulation No. 25 of 2016 concerning management and Ijen-Raung Arabica Coffee trading system. Sumber wringin District was designated as an Agropolitan Center or Agribusiness Sub Terminal, in Sukorejo Village, with superior commodities of coffee and other. The Arabica coffee production in Sumber Wringin district reaches $542 \mathrm{t}$ with a productivity of $0.38 \mathrm{t} \mathrm{ha}^{-1}$, while the Robusta coffee production in Sumber Wringin District reached $744.75 \mathrm{t}$ with a productivity of $0.45 \mathrm{tha}^{-1}$ (Sumber Wringin District in numbers, 2019). The production and the productivity of the two types of coffee is the largest compared to other sub-districts, it is also linear with land area where the Sumber Wringin sources have the largest land area 
compared to other districts. This factor is what makes coffee the main commodity for regional formation Agropolitan Bondowoso Regency which is centered in Sumber Wringin District.

\section{Life cycle assessment of smallholder coffee plantation}

Life cycle assessment (LCA) is a mechanism for analysing and calculating the total environmental impact of a product at every stage of its life cycle, namely the preparation of raw materials, the production process, and the disposal of the product (ISO 50001:2018). The results of the LCA can be used as a basis for decision making by policymakers, producers, and consumers when choosing products and production processes that are environmentally sustainable. The LCA method in its application consists of the following stages:

1) Setting the goals and the scope of research is the first step in the LCA method. The LCA of the selected product includes the analysis of coffee plantations, transportation of raw materials and supporting materials, coffee processing, and handling of production waste.

2) Inventory analysis is carried out by taking an inventory of all relevant input and output flows in units of mass and energy per $\mathrm{kg}$ of coffee produced.

3) Impact assessment is the stage of analysing the results of the previously conducted inventory. The impact assessment of all resources in the inventory was performed to obtain environmental impact categories per use of $1 \mathrm{~kg}$ of coffee. The environmental impact category contains the amount of greenhouse gas (GHG) emissions and the energy efficiency of the coffee product during its life cycle. The resulting $\mathrm{CO}_{2}$ emission output will be represented in the form of global warming potential (GWP 100), which is a measure of the relative amount of heat trapped in greenhouse gases. The amount of heat trapped in a certain gas is compared to the $\mathrm{CO}_{2}$ gas with the same mass over 100 years (Brander, 2012; Chaerul et al., 2016).

\section{Objective and scope}

The objective of the research was to identify and quantify the potential environmental impact associated with coffee production and processing in Ijen Plateau of Indonesia and to identify the activities that are not performed sustainably as well as suggest a number of improvement options towards the sustainability of the system studied. These including the stages of land use change, farming work, transportation, milling and processing in this area which will effect to energy and GHG balances.

The scope of this LCA research includes several stages, which can be seen in Figure 1. The first stage in this study included the planting stage. The second stage is the transportation stage, focusing on the transportation of coffee cherries from the plantation to the processing plant. The last stage is the coffee processing stage, including the production process and the disposal of the coffee processing waste.

\section{METHODOLOGY}

The study was conducted in Ijen Plateau Coffee Plantation in Bondowoso Regency of East Java Province - Indonesia, from June to December 2020. This research area is located around $1020 \mathrm{~km}$ from Jakarta - Indonesian capital city. Sumber Wringin is located on the slopes of the Ijen Plateau of Indonesia which has altitute of 900 until 1200 meters above sea level. In terms of climate, Ijen Crater has types $\mathrm{C}$ and D climate, according to Schmidt and Ferguson, namely climates with an average rainfall of $1500-4000 \mathrm{~mm}$ per year. Meanwhile, in the south, it has an average rainfall of 3000-5000 mm per year and the minimum air temperature reaches 2 degrees Celsius and a maximum of 18 degrees Celsius (Central Statistical Beareau of Indonesia/ BPS, 2019). The data was taken by direct survey with in depth interview and questinanaires as well as laboratory experiment of the waste product. The research data were obtained from from farmer respondents, coffee milling industry and regency staff.

\section{System boundaries and functional unit}

For this study, the functional unit chosen was $1 \mathrm{~kg}$ coffee beans processed. All the inputs and outputs in the Life Cycle Inventory (LCI) and impact scores produced in the life cycles impact assessment phase of this LCA study were expressed with reference to the functional unit. The system boundary used the cradle to gate system (Figure 2).

The studies presented do not consider different farming system and regions. However, empirical evidence suggests that the major differences 


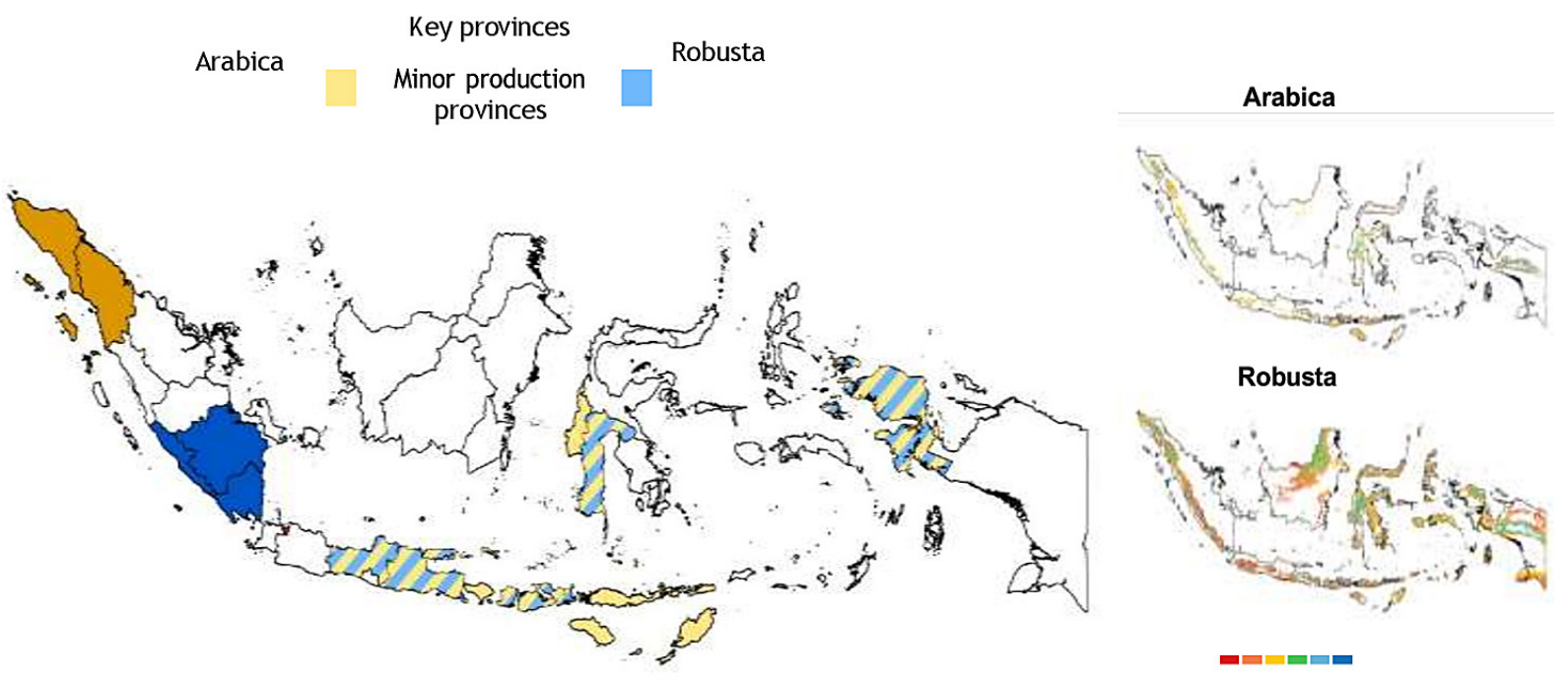

Figure 1. Key coffee production in Indonesia (Unique, 2019)

exist betweeen the farming system and location in one province of Indonesia. The knowledge of these differences and the factor leading to different results can contribute to a more environmentally sound development of coffee production in Indonesia and other countries around the world.

\section{Data base}

This research consisted of three stages: the preliminary stage, data collection and analysis, and interpretation of research results. The first stage aimed to ensure the availability of the required data and perform a literature review to identify problems. Moreover, it involved defining the research objective. The second stage entailed designing the data collection process. In addition, data was obtained from experts using questionnaires and interviews. A literature review was also performed to support these data. The data were collected and analysed at the data analysis stage. The third stage was the interpretation of the results based on the data analysis methods.

\section{Discription of the coffee production process}

Currently, there are two ways of processing coffee from fresh fruit to a product ready for consumption, namely the fully wet process and the dry process with the processing stages, as shown in Figure 3 (Alves et al., 2017; Coltro et al. 2015; Mhilu, 2015). The wet processing stages were

\section{COFFEE PRODUCTION PROCESS IN GENERAL}

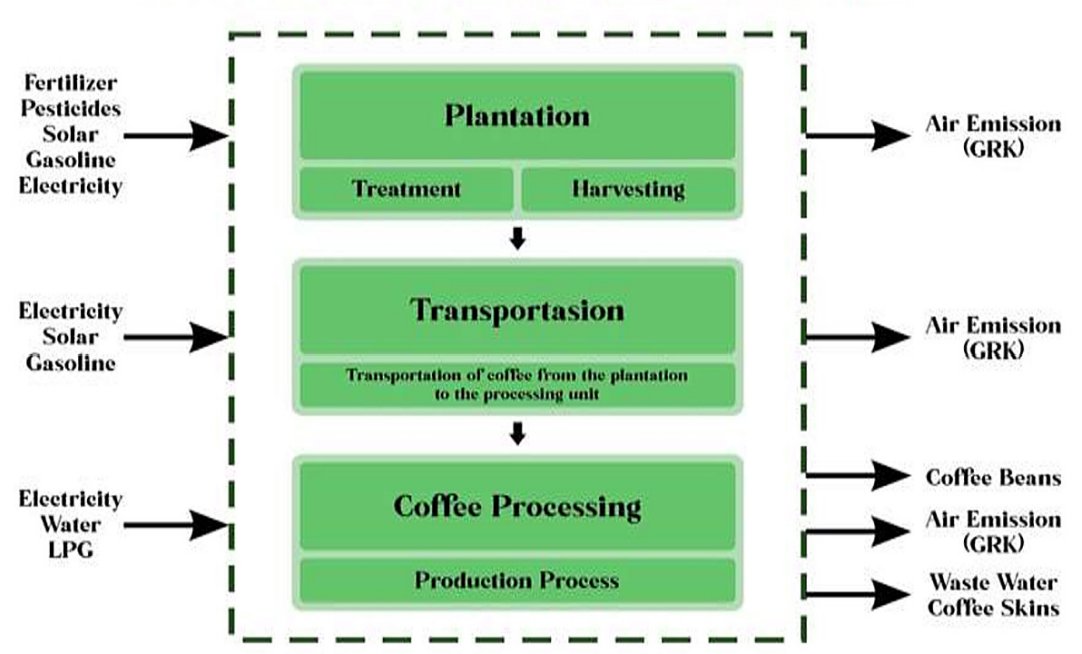

Figure 2. System boundary of this research 
harvesting coffee fruit, receiving fruit, siphon tank for separating ripe fruit from unripe fruit and attacked by pests, peeling wet fruit skin (pulping), fermentation of wet coffee with the shells, washing, drying coffee shells without a layer of mucus, cleaning, peeling dry skin (hulling), classification of quality based on size/ grading (Mussato et al, 2011; Murthy et al., 2017). Meawhile, the dry processing is relatively simpler if compared to wet processing. The stages of dry processing are coffee fruit harvesting, wet log drying, cleaning, dry skin stripping, grading, quality classification based on density and colour (sortation) and storage.

\section{Energy potential from coffee waste}

The potential waste obtained from the dry and wet coffee processing stages is wet fruit skin, liquid waste which contains mucus, as well as dry logs and dry shells (Murthy et al., 2017; Panhuysen \& Pierrot, 2015). The fruit of coffee or often referred to as wet coffee logs yields a moisture content between $60-65 \%$. Coffee beans are still protected by fruit skin, pulp, mucus layer, horn skin and dry epidermis, containing $35 \%$ pectin, $30 \%$ reducing sugar, $20 \%$ non-reducing sugar as well as $17 \%$ cellulose and ash (Amaia et al. 2019). Furthermore, Harsono et al (2019) stated that dry coffee fruit consisted of $55.4 \%$ coffee beans, $28.7 \%$ dry pulp, $11.9 \%$ shell, and the remaining $4.9 \%$ was dry mucus. The dried coffee pulp consists of $12.6 \%$ water; $21 \%$ crude fibre; $8.3 \%$ ash; $12.4 \%$ reducing sugars; $44.4 \%$ nitrogen extract. Dry shell consists of $7.8 \%$ water; $77 \%$ crude fibre; $0.5 \%$ ash, and $18.9 \%$ nitrogen extract (Selvamurugan et al., 2011). In the full wet processing process, the water consumption can reach $7-9 \mathrm{~m}^{3}$ per ton of processed coffee fruit
(Rudraguda, 2017). The water requirements for the washing process range from $5-6 \mathrm{~m}^{3}$ per tonne of coffee beans with shells (Chala et al., 2017; Harsono et al., 2018), reported that 1 ha of coffee plantation area will produce about 1.8 tonnes of fresh waste, equivalent to the production of 630 $\mathrm{kg}$ of waste flour.

Therefore, the solid and liquid waste generated from the wet coffee processing stage is very high. The efforts to use coffee processing waste both in solid and liquid form into products that have a higher economic value need to be made. The anatomic of coffee cherry fruit can be seen in Figure 3.

The results of the mass balance analysis of coffee beans obtained that from $29 \mathrm{~kg}$ of dry-processed coffee \%) dry logs consisting of $15.95 \mathrm{~kg}$ of coffee beans $(55 \%)$ and $13.05 \mathrm{~kg}$ of dry logs (45\%). Dry logs consist of shells, mucus and fruit skins with a dry weight ratio of 11.9: 4.9: 28.7. Dry log shells contain reducing sugars, non-reducing sugars and pectated compounds reaching $12.4 \% ; 2.02 \%$ and $6.52 \%$, respectively as well as $10.7 \%$ crude protein and $20.8 \%$ crude fibre (Cruz and Crnkovic, 2015; Harsono et al., 2018).

Sustainable industrial development is needed to preserve the environment while supporting coffee production. In order to achieve sustainable outcomes, the management and conversion of natural resources, technology, as well as involvement of institutions and stakeholders are important aspects to consider. The technology used must be in accordance with the carrying capacity of natural resources to prevent environmental degradation. The measurement of the environmental impact that arises from the existence of the industry should be performed based on environmental indicators.

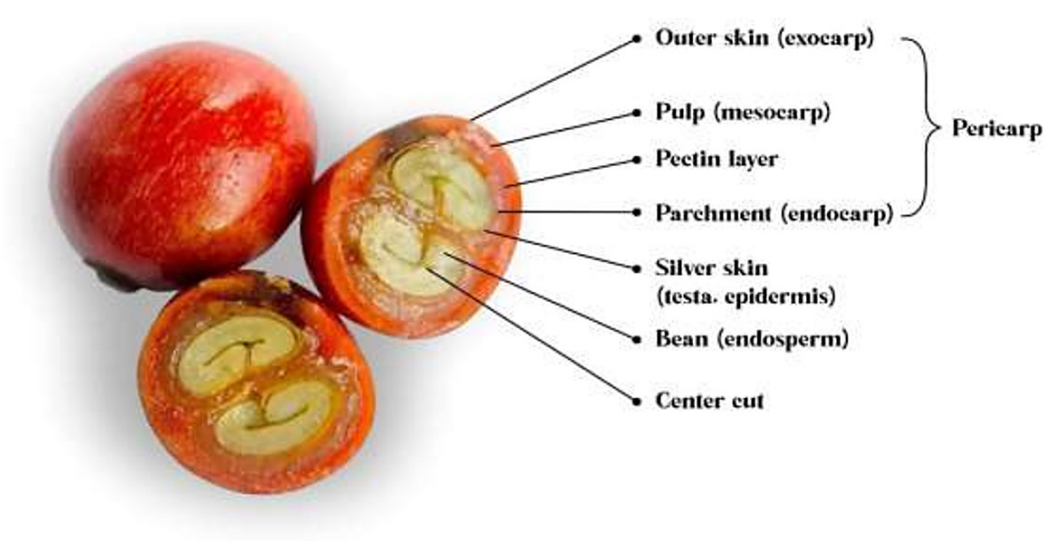

Figure 3. Schematic the anatomy of a coffee cherry 


\section{Energy balances (input and output energies)}

The calculation of the number of $\mathrm{CO}_{2}$-eq emissions per $\mathrm{kg}$ of coffee is in accordance with the IPCC (2006) guideline, as shown below.

$$
\mathrm{E}=\mathrm{AD} \times \mathrm{EF}
$$

where: $\mathrm{E}=$ Emission ( $\mathrm{g} /$ ton $)$,

$\mathrm{AD}=$ Activity data,

$\mathrm{EF}=$ Material emission factor $\left(\mathrm{kg} \mathrm{CO}_{2} \mathrm{eq} / \mathrm{AD}\right)$

The estimated net energy is in the form of standard energy units (joules, J). Then, to calculate the energy required for producing $1 \mathrm{~kg}$ of coffee, equation 2 is used.

$$
\mathrm{En}=\mathrm{n} \times \mathrm{CV}
$$

where: $\operatorname{En}=$ Energy $(\mathrm{J})$,

$\mathrm{n}=$ Inventory volume,

$\mathrm{CV}=$ Calorific value $(\mathrm{MJ} / \mathrm{g})$.

Energy efficiency is expressed in the form of net energy value (NEV) and net energy ratio (NER). NER and NEV calculations are shown in equation 3 and 4, respectively.

$$
\begin{gathered}
\mathrm{NEV}=\sum \text { Eno }-\sum \text { Eni } \\
\mathrm{NER}=\left(\sum \text { Eno }\right) /\left(\sum \text { Eni }\right)
\end{gathered}
$$

where: $\mathrm{NEV}=$ Net energy value, $\mathrm{NER}=$ Net energy ratio,

$\sum$ Eno $=$ Total energy output, $\sum$ Eni $=$ Total energy input.
Energy performance which is evaluated as effective, has a positive NEV value and a NER value above 1 .

\section{Coffee Production stage}

The production stage includes the processing of the Arabica and Robusta ground coffee, which begins with the process of receiving the harvest or coffee logs, followed by pulping, fermentation, washing, drying, stripping the coffee husks, roasting, grinding, and packaging ground coffee from mass balance calculations, where the energy balance considers the material input and output of products and waste generated. The liquid and solid waste generated results in water pollution, and if there is no handling of waste due to the use of fuel from coffee processing, air pollution and potential acidification may be caused due to GHG and other emissions.

The liquid waste should be subject to chemical coagulation and flocculation processes as they are more effective, cost effective and easy to conduct. Meanwhile, the solid waste from coffee husks could be used for the production of biogas, because the coffee husks contain sugar. Liquid waste may also be used. Hareesh et al. (2017) stated that $30 \mathrm{~kg}$ of coffee husks mixed with cow dung can produce $670 \mathrm{~L}$ of methane after 72 days and can be turned into briquettes by drying it and turning it into wine and then printing it. In order

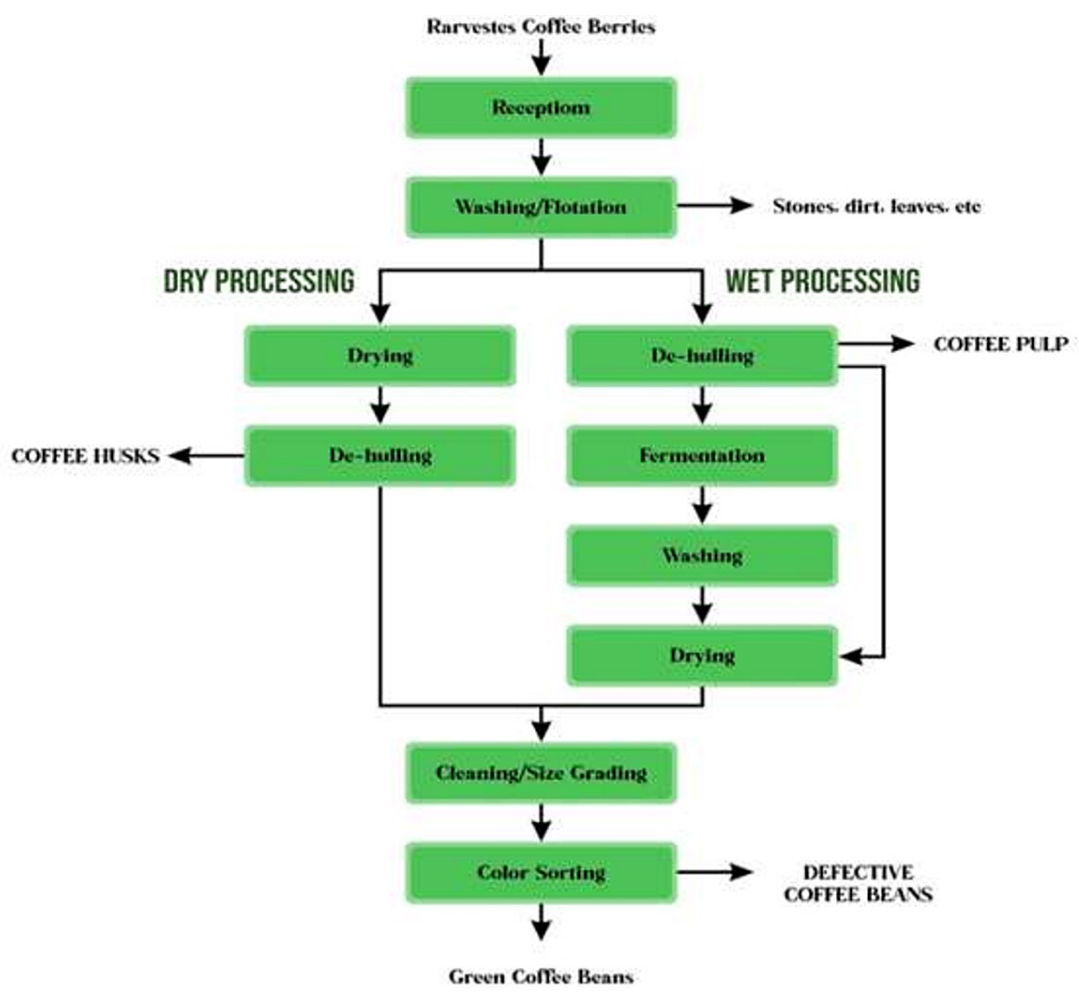

Figure 4. Coffee processing 
to reduce emissions, fuels should be replaced by biofuels. This is because the energy content of biofuel is approximately $23 \mathrm{MJ} \mathrm{L}^{-1}$ which is lower than that of gasoline and diesel, which have an energy content of 35 to $40 \mathrm{MJ} \mathrm{L}^{-1}$ (IPCC, 2007).

\section{Coffee Processing}

Currently, there are two ways of processing coffee from fresh fruit to ready for consumption, namely the fully wet process and the dry process with the processing stages as shown in Figure 4 (Amaiea et al., 2017;

The dry processing is still widely applied by the Robusta coffee farmers, and large plantation companies for inferior coffee fruit, namely young, dry and floating fruit. Dry coffee processing is relatively simpler if compared to wet processing. The stages of dry processing are coffee fruit harvesting, wet log drying, cleaning, dry skin stripping, grading, quality classification based on density and colour (sortation) and storage.

The wet processing stages were harvesting coffee fruit, receiving fruit, siphon tank for separating ripe fruit from easy fruit and being attacked by pests, peeling wet fruit skin (pulping), fermentation of wet coffee with the shells, washing, drying coffee shells without a layer of mucus, cleaning, peeling dry skin (hulling), classification of quality based on size (grading) (Nopenen et al., 2006), quality classification based on density and colour (sortation) and storage (Clarke \& Macrae, 1989). Peeling the coffee fruit skin (pulping) is one of the stages of the coffee processing process that distinguishes between the wet and dry coffee processing. A wet coffee peeler (pulpier) machine is used to separate or remove the rind components from the coffee parts pi with shells (Wilson et al., 2010).

\section{RESULTS}

\section{Energy balances}

The plantation stage includes the coffee farming stage, which involves pesticide application carried out once every four months in 20 ha and 124 ha of the Arabica and Robusta coffee fields, respectively, by applying pesticides at a rate of $0.5 \mathrm{~kg} / \mathrm{ha}$. The emission factors are listed in Table 1.

\section{Emission}

$1 \mathrm{~kg}$ pesticides is equal to $11,025 \mathrm{~kg} \mathrm{CO}_{2}$-eq (Pehnelt el al., 2012). The data from the calculation of the emission of pesticide application to the Arabica and Robusta coffee plants are shown in Table 2.

\section{Transportation stage inventory}

The transportation stage in this study involves the transportation of the coffee harvest to the Sukorejo village coffee processing unit via a motorbike. The data to be observed in this study include the use of nuclear fuel as a source of emissions. The distances from the Arabica and Robusta coffee plantations are $8 \mathrm{~km}$ and $10 \mathrm{~km}$, respectively. The results of energy calculations for the maintenance and transportation stages are shown in Table 3.

The data from the calculation above shows that the energy value obtained for the Arabica coffee transportation and treatment were 152.36 $\mathrm{MJ} \mathrm{t}^{-1}$ and $74.54 \mathrm{MJ} \mathrm{t}^{-1}$, respectively, while the Robusta coffee had a treatment energy value of 158.68 $\mathrm{MJ} \mathrm{t}^{-1}$ and 162.74. $\mathrm{MJ} \mathrm{t}^{-1}$, respectively. The burning of fuel to produce this required energy results in emissions, such as that of GHGs.

Table 1. Emission factor per unit $\mathrm{CO}_{2}$

\begin{tabular}{|c|c|c|c|}
\hline Emission source & Unit & $\mathrm{kg} \mathrm{C02-eq} \mathrm{/} \mathrm{Unit}$ & Reference \\
\hline Pesticides & $\mathrm{kg}$ & 11.025 & Pehnelt et al. (2012) \\
\hline
\end{tabular}

Table 2. Calculation of pesticides emission

\begin{tabular}{|c|c|c|}
\hline Type of coffee & Areas (ha) & Emission $\left(\mathrm{kg} \mathrm{CO}_{2}\right.$-eq) \\
\hline Arabica & 20 & 330.75 \\
\hline Robusta & 124 & 2050.65 \\
\hline
\end{tabular}

Table 3. Calculation of energy of maintenance and transporation

\begin{tabular}{|c|c|c|}
\hline \multirow{2}{*}{ Type of coffee } & Maintenance & Transportation \\
\cline { 2 - 3 } & Energy $\left(\mathrm{MJ} \mathrm{t} \mathrm{t}^{-1}\right)$ & Energy $\left(\mathrm{MJ} \mathrm{t}^{-1}\right)$ \\
\hline Arabica & 74.54 & 152.36 \\
\hline Robusta & 158.68 & 162.74 \\
\hline
\end{tabular}




\section{Ground coffee processing inventory}

The data obtained from the research results were included the mass and energy balance data as well as the calculation of emissions along the life cycle of processing Robusta and Arabica wet coffee. The emission values for the Arabica and Robusta coffee processing are shown in Table 4.

The waste produced was in the form of liquid and solid. The liquid waste produced by the Arabica coffee processing was $3728.92 \mathrm{~kg}$, with an annual total waste of $74578.4 \mathrm{~kg}$. For Robusta, the liquid waste was $4325.08 \mathrm{~kg}$ and the annual waste was $536309.92 \mathrm{~kg}$. The liquid waste contains high concentrations of pollutants in the form of organic materials produced from pulp processing, fermentation, and washing (Enden and Calvert, 2002).

The solid waste produced from processing the Arabica and Robusta coffee amounted to
$318.87 \mathrm{~kg}$ and $235.35 \mathrm{~kg}$, respectively, with a total amount of waste of $6377.4 \mathrm{~kg}$ and $29183.4 \mathrm{~kg}$ year $^{-1}$. The solid waste was majorly composed of coffee husk for both kinds of coffee.

\section{GHG emissions}

This stage includes the treatment of pesticides on the Arabica and Robusta coffee plantations, which produced the GHG emissions of $16.4 \mathrm{~kg} \mathrm{CO}_{2}$ eq ha ${ }^{-1}$ and $102.53 \mathrm{~kg} \mathrm{CO}_{2}$ eq ha $^{-1}$ respectively, and spray engine fuel emissions of $4874.81 \mathrm{~g} \mathrm{CO} \mathrm{eq} \mathrm{t}^{-1}, 80.13 \mathrm{~g} \mathrm{NO}_{2} \mathrm{t}^{-1}, 1.74 \mathrm{~g} \mathrm{SO}_{2} \mathrm{t}^{-1}$ and $10247.23 \mathrm{gCO}_{2}$-eq t-1 ${ }^{-1}, 168.45 \mathrm{~g} \mathrm{NO}_{2} \mathrm{t}^{-1}, 3.65$ $\mathrm{g} \mathrm{SO}_{2} \mathrm{t}^{-1}$, respectively. GHG emissions may be significantly reduced at this stage by replacing pesticides with organic pesticides and replacing gasoline with biofuels.

Table 4. Emission of processing coffee of Arabica and Robusta

\begin{tabular}{|c|c|c|c|c|c|c|}
\hline \multirow{3}{*}{ Emission produce } & \multicolumn{6}{|c|}{ Emission ( $\mathrm{g} \mathrm{t}^{-1}$ coffee $)$} \\
\hline & \multicolumn{3}{|c|}{ Arabica coffee } & \multicolumn{3}{|c|}{ Robusta coffee } \\
\hline & $\mathrm{CO}_{2}$ & $\mathrm{NO}_{2}$ & $\mathrm{SO}_{2}$ & $\mathrm{CO}_{2}$ & $\mathrm{NO}_{2}$ & $\mathrm{SO}_{2}$ \\
\hline Sprayer (Bensen) & 4874.81 & 80.13 & 1.74 & $10,247.23$ & 168.45 & 3.65 \\
\hline Motor (Benzen) & $9,964.69$ & 163.80 & 3.55 & $10,643.62$ & 174.96 & 3.79 \\
\hline Pulping (Benzene) & $7,814.04$ & 128.45 & 2.78 & $7,814.04$ & 128.45 & 2.78 \\
\hline Washing (Benzene) & $5,737.18$ & 94.31 & 2.04 & $6,300.15$ & 103.56 & 2.24 \\
\hline Stripping (Diesel Oil) & $5,426.09$ & 89.20 & 1.93 & $6,489.67$ & 106.68 & 2.31 \\
\hline Roasting (Liquid gas) & $60,470.28$ & 994.03 & 21.54 & $72,820.57$ & $1,197 / 05$ & 25.94 \\
\hline Milling (Diesel Oil) & $4,390.76$ & 72.18 & 1.56 & $5,247.26$ & 86.26 & 1.87 \\
\hline
\end{tabular}

Table 5. Input and output material for processing coffee per ton of product

\begin{tabular}{|c|c|c|c|c|c|c|}
\hline \multirow{3}{*}{ Material $(\mathrm{kg})$} & \multicolumn{3}{|c|}{ Arabica coffee } & \multicolumn{3}{|c|}{ Robusta coffee } \\
\hline & \multirow[t]{2}{*}{ Input } & \multicolumn{2}{|c|}{ Output } & \multirow[t]{2}{*}{ Input } & \multicolumn{2}{|l|}{ Output } \\
\hline & & Coffee powder $(\mathrm{kg})$ & Waste $(\mathrm{kg})$ & & Coffee powder $(\mathrm{kg})$ & Waste $(\mathrm{kg})$ \\
\hline Coffee logs & 1,000 & & & 1,000 & & \\
\hline Water & $3,824.50$ & & & $3,268.83$ & & \\
\hline Total Input & $4,824.50$ & & & $4,864,83$ & & \\
\hline Coffee powder & & 264,07 & & & 221.04 & \\
\hline Coffee Husk & & & 208,73 & & & 297.03 \\
\hline Liquid waste stripping & & & $1,351.89$ & & & $1,027.83$ \\
\hline Liquid waste fermentation & & & 301.57 & & & 151.14 \\
\hline Mucus leaching & & & 254.55 & & & 293.84 \\
\hline Washing water waste & & & $2,111.67$ & & & $1,812.52$ \\
\hline Steam drying water & & & 494.67 & & & 413.44 \\
\hline Stripping epidermis & & & 26.62 & & & 21.84 \\
\hline Roasting water vapor & & & 36.01 & & & 30.14 \\
\hline Amount of waste & & & $4,560.43$ & & & $4,047.79$ \\
\hline Total output & & & $4,824.50$ & & & $4,268.83$ \\
\hline
\end{tabular}




\section{Transport stages}

This stage includes the stage of transporting coffee logs to the Sukorejo village coffee processing unit, which is $9 \mathrm{~km}$ from the Robusta coffee plantation and $15 \mathrm{~km}$ from the Arabica coffee plantation, using a motorbike. GHG emissions result from burning motorcycle fuel. The transportation of the Arabica coffee logs produces the emissions of $9964.69 \mathrm{~g} \mathrm{CO}_{2}$ eq t $^{-1}, 163.8 \mathrm{~g} \mathrm{NO}_{2} \mathrm{t}^{-1}$, and $3.55 \mathrm{~g} \mathrm{SO}_{2} \mathrm{t}^{-1}$. For the Robusta coffee, these values are $10643.62 \mathrm{~g} \mathrm{CO}_{2}$ eq t-1 $17496 \mathrm{~g} \mathrm{NO}_{2} \mathrm{t}^{-1}$, and $3.79 \mathrm{~g} \mathrm{SO}_{2} \mathrm{t}^{-1}$. Therefore, the fossil fuel used here should be replaced by biofuel.

\section{Comparison of energy use in the Arabica and Robusta coffee processing}

The energy needed for wet coffee processing comes from fuel and electricity. A comparison of energy input and output during coffee processing for the two kinds of coffee is shown in Table 6 .

The total input energy for the Arabica coffee processing was $1466.557 \mathrm{MJ} \mathrm{t}^{-1}$, while the Robusta coffee used an energy input of 1681.975 $\mathrm{MJ} \mathrm{t}^{-1}$. Thus, Robusta processing consumes greater amounts of energy than Arabica processing. This can be explained by the fact that the yield of each stage of the processing cycle is larger, and so it takes a longer time to operate the processing machine.

\section{Energy efficiency}

Energy efficiency in this LCA study was determined by measuring the net energy from the processing life cycle of the Arabica and Robusta coffee. The comparison of the net energy of the Arabica and Robusta coffee processing is shown in Table 7.

The Arabica and Robusta coffee processing had NER values of 7,232 and 6,285, respectively. This was caused by the differences in the input energy between Arabica and Robusta coffee processing. Arabica processing carries a greater NEV value than that of Robusta, the difference being 0.3 $\mathrm{MJ} \mathrm{kg}{ }^{-1}$ of ground coffee. The energy consumption of the Arabica and Robusta coffee processing life cycles is said to be efficient if a positive NEV value and an NER value of higher than 1 is achieved (Killian et al. 2013; Nugroho, 2014).

\section{Comparison of emissions from Arabica and Robusta coffee processing}

Emissions (exhaust gas) come from the combustion of fuel (gasoline, diesel, and LPG) during the maintenance, transportation, and processing stages of pulper, hullers, washers, grinding machines, and roasting machines. The value of the resulting emissions processing of both Arabica and Robusta coffee is shown in Figure 5.

Table 6. Comparison of the input and output energy from the Arabica and Robusta coffee processing

\begin{tabular}{|c|c|c|c|c|}
\hline \multirow{2}{*}{ Energy input } & \multicolumn{2}{|c|}{ Arabica coffee } & \multicolumn{2}{|c|}{ Robusta coffee } \\
\hline & Electricity energy $\left(\mathrm{MJ} \mathrm{t}^{-1}\right)$ & Fuel energy $\mathrm{MJ} \mathrm{t}^{-1}$ ) & Electricity energy $\left(\mathrm{MJ} \mathrm{t}^{-1}\right)$ & Fuel energy $\left(\mathrm{MJ} \mathrm{t}^{-1}\right)$ \\
\hline Spray engine & & 74.54 & & 156.68 \\
\hline Motorcycle & & 152.56 & & 162.75 \\
\hline Pulper & & 12.79 & & 13.44 \\
\hline Washing & & 8.92 & & 9.72 \\
\hline Stripping & & 38.85 & & 38.77 \\
\hline Roasting & 539.74 & 597.14 & 656.35 & 601.36 \\
\hline Milling & & 42.21 & & 42.28 \\
\hline Total & 539.74 & 926.82 & 656.47 & 1024.98 \\
\hline Total input & \multicolumn{2}{|c|}{1466.56} & \multicolumn{2}{|c|}{1681.98} \\
\hline \multicolumn{5}{|l|}{ Energy output } \\
\hline Coffee powder & \multicolumn{2}{|c|}{10.65} & \multicolumn{2}{|c|}{10.56} \\
\hline
\end{tabular}

Table 7. Comparison of NER, and NEV per kg of Arabica powder and coffee powder

\begin{tabular}{|l|c|c|}
\hline \multicolumn{1}{|c|}{ Type of energi } & Arabica coffee & Robusta coffee \\
\hline Input energy & 1.46 & 1.68 \\
\hline Energy output & 10.56 & 10.56 \\
\hline Net energy ratio & 7.23 & 6.28 \\
\hline Net energy value & 9.1 & 8,88 \\
\hline
\end{tabular}




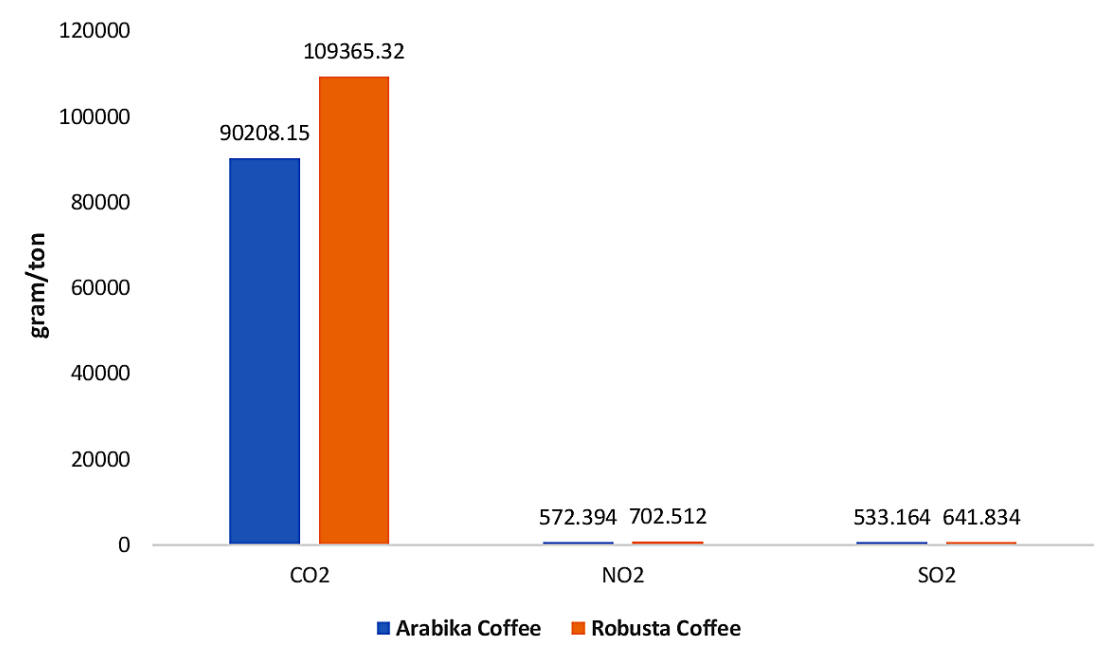

Figure 5. Emission value of Arabica and Robusta coffee processing

Figure 5 shows that the emissions released from the processing of the Robusta coffee are greater than those from the Arabica coffee. The Robusta coffee processing with a emission values of 90,208.15 $\mathrm{g} \mathrm{CO}_{2}$-eq $\mathrm{t}^{-1}, 572,394 \mathrm{~g} \mathrm{NO}_{2} \mathrm{t}^{-1}$, and $533,164 \mathrm{~g} \mathrm{SO}_{2} \mathrm{t}^{-1}$, while for the Arabica coffee, these values are $109,365.32 \mathrm{~g} \mathrm{CO}_{2}$-eq $\mathrm{t}^{-1}, 702,512$ $\mathrm{g} \mathrm{t}^{-1}$, and $641,834 \mathrm{~g} \mathrm{t}^{-1}$ of coffee, respectively. The difference in the results of these emissions stems from the differences in fuel consumption required for processing.

The value of the potential greenhouse effect corresponds to the $\mathrm{CO}_{2}$ equivalent value, while the acidification value corresponds to the $\mathrm{SO}_{2}$ equivalent. The magnitude of the greenhouse effect and acidification of Arabica and Robusta coffee processing in the community coffee processing in Ijen areas as shown in Figure 6.

\section{DISCUSSION}

The interpretation stage is the conclusion stage and the determination of recommendations if necessary, which are obtained based on the analysis that has been carried out at every stage of the processing of the Arabica and Robusta coffee powder in the research area.

This stage includes the treatment of pesticides on the Arabica and Robusta coffee plants which produce GHG emissions from the Arabica and Robusta coffee plantations of $16.4 \mathrm{~kg} \mathrm{CO}_{2}^{-}$ eq ha ${ }^{-1}$ and $102.53 \mathrm{~kg} \mathrm{CO}_{2}$-eq ha ${ }^{-1}$ respectively and fuel emission for spray machines 4874,81 $\mathrm{g} \mathrm{CO}_{2}$ eq t$^{-1}, 80.13 \mathrm{~g} \mathrm{NO}_{2} \mathrm{t}^{-1}, 1.74 \mathrm{~g} \mathrm{SO}_{2} \mathrm{t}^{-1}$ and 10247.23 g CO$_{2}$-eq t ${ }^{-1}, 168.45 \mathrm{~g} \mathrm{NO}_{2} \mathrm{t}^{-1}, 3.65 \mathrm{~g}^{2}$ $\mathrm{SO}_{2}$-eq $\mathrm{t}^{-1}$. This stage has the potential to produce environmental impacts in the form of GHG. The

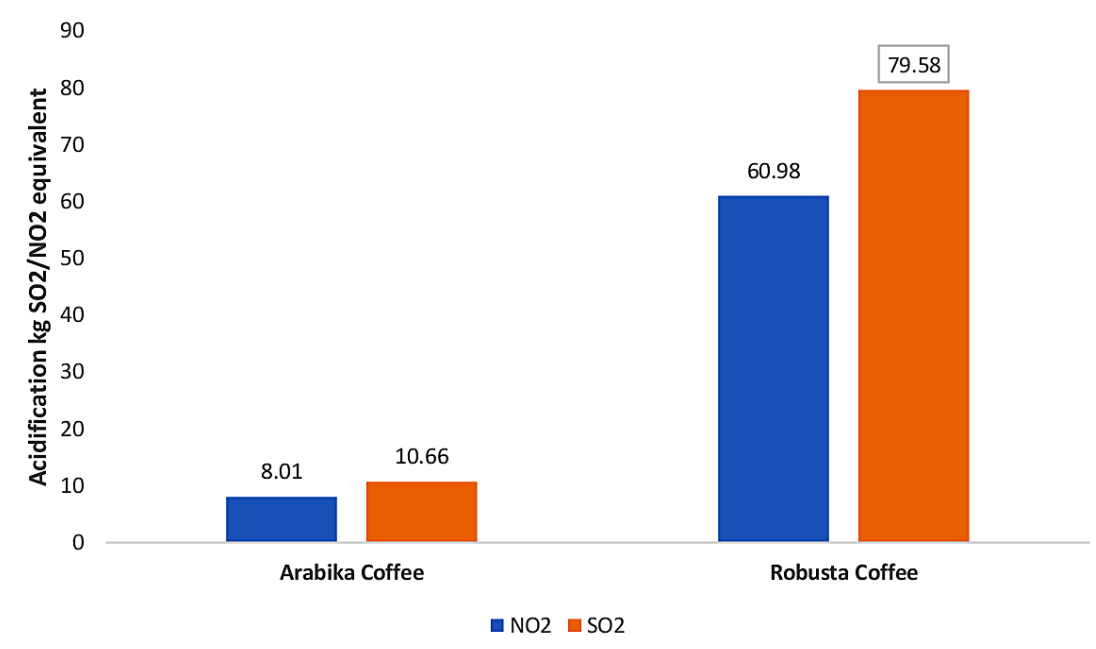

Figure 6. Potential greenhouse effect Arabica and Robusta coffee processing 
recommendation proposed is a reduction in the value of emissions by replacing pesticides with organic pesticides and replacing gasoline with biofuels.

\section{Transport stages}

This stage includes the stage of transportingthe coffee logs to the Sukorejo Village coffee processing unit using a motorbike. This stage has the potential to generate GHG environmental impacts due to the emissions resulting from combusting motorcycle fuel. For the transportation of the Arabica coffee logs, it produces emissions of 9964.69 $\mathrm{g} \mathrm{CO}_{2} \mathrm{t}^{-1}, 163.8 \mathrm{~g} \mathrm{NO}_{2} \mathrm{t}^{-1}, 3.55 \mathrm{~g} \mathrm{SO}_{2} \mathrm{t}^{-1}$ and for the transportation of Robusta coffee $10643.62 \mathrm{~g}$ $\mathrm{CO}_{2} \mathrm{t}^{-1}, 174,96 \mathrm{~g} \mathrm{NO}_{2} \mathrm{t}^{-1}, 3.79 \mathrm{~g} \mathrm{SO}_{2} \mathrm{t}^{-1}$. Recommendations for improvement by replacing fuel with environmentally friendly biofuels.

\section{Coffee processing stages}

This production stage includes the processing of the Arabica and Robusta ground coffee, which begins with the process of receiving the harvest or coffee logs, followed by pulping, fermentation, washing, drying, stripping the coffee husks, roasting, grinding and packaging ground coffee from the mass balance calculation and energy balance contains material input and output of products and waste produced. The resulting liquid and solid waste will cause water pollution and water ecosystems if there is no handling of temporary waste due to the use of fuel from coffee processing, which in turn will cause emissions into the air which have the potential to cause acidification and GHG.

The recommendation for handling the coffee liquid waste is the chemical coagulation and floccation process, which is a process that is studied to handle the coffee processing liquid waste because it is considered to be more effective, cheap and easy to conduct. Meanwhile, the handling of solid waste from coffee husks involves using it to become biogas because the coffee husks in the stripping process still contain sufficient amount of sugar that has the potential for the formation of biogas together with liquid waste from wet processing. According to Braham and Bressani (1979). $30 \mathrm{~kg}$ of coffee skin mixed with cow dung can produce 670 liters of methane after 72 days and turned it into briquettes by drying it and turning it into wine and then printing it. Meanwhile, the emissions produced can be reduced by replacing fuel with environmentally friendly counterparts such as biofuels. This is because the energy content of biofuel is around 23 to $23 \mathrm{MJ} \mathrm{L}^{-1}$, which is smaller than that of gasoline and diesel which has an energy content of 35 to $40 \mathrm{MJ} \mathrm{L}^{-1}$ (IPCC, 2007).

\section{CONCLUSIONS}

The potential environmental impact of the Robusta and Arabica coffee in the coffee processing in Sukorejo - Bondowoso is significant due to the release of solid and liquid waste into the environment. Potential GHG emission of the Arabica coffee is $98.7 \mathrm{~kg} \mathrm{CO}_{2}$-eq kg-1 and for Robusta it is $119.6 \mathrm{~kg} \mathrm{CO}_{2}$-eq kg-1. The potential GHG emission rate of the Arabica coffee is 1.804 $\mathrm{t} \mathrm{CO}_{2}$-eq year-1. For the Robusta coffee processing, the potential GHG emission is $13.56 \mathrm{t} \mathrm{CO}_{2}-$ eq year $^{-1}$. The potential for acidification in the case of the Arabica coffee processing is $8,013 \mathrm{~kg}$ $\mathrm{NO}_{2}$ eq year ${ }^{-1}$ and $10.663 \mathrm{~kg} \mathrm{SO}_{2}$-eq year ${ }^{-1}$. For the Robusta coffee processing process, the acidification potential is $60.97 \mathrm{~kg} \mathrm{NO}_{2}$-eq year ${ }^{-1}$ and $79.58 \mathrm{~kg} \mathrm{SO}_{2}$-eq year-1. The Robusta coffee has a greater environmental impact than processing the Arabica coffee. Alternative recommendations for increasing product efficiency are the chemical treatment of liquid waste, using solid waste as biogas and briquettes, and replacing gasoline with biofuel to reduce emissions.

\section{Acknowledgements}

The Association of Coffee Smallholder of Usaha Tani 4 in Sukorejo Bondowoso, East Java Province Indonesia who gave us valuable information regarding this work. Special thanks to all coffee plantations site managers and the smallholder plantation who gave us time and provided data as well as extending hospitality for the duration of the work. Finally, we thank the reviewers for their constructive comments and valuable suggestions.

\section{REFERENCES}

1. Alves R.C., Rodrigues F., Nunes M.A.A., Vinha A.F., Oliveira M.B.P.P. State of the art in coffee processing by-products. In: Galanakis C., editor. Handbook of Coffee Processing By-Products: Sustainable Applications. Academic Press-Elsevier; London, UK: 2017. pp. 1-26 
2. Amaia Iriondo-DeHond, ${ }^{1}$ Maite Iriondo-DeHond, and María Dolores del Castilloo, 2019, Applications of Compounds from Coffee Processing By-Products, Biomolecules. ; 10(9): 1219.

3. Azwar A.B. 2012. Intensifikasi Kopi Jadi Program Unggulan Baru. Media Perkebunan 99

4. Brander, M. 2012. Greenhouse Gases $\mathrm{CO}_{2}, \mathrm{CO}_{2 e}$ dan Carbon. European Commission.

5. Central Bureau of Statistics (BPS), 2017, Data Statitisk Indonesia 2017

6. Chaerul M, Dirgantara GG, Akib R. 2016. Prediction of Greenhouse Gasses Emission from Municipal Solid Waste Sector in Kendari city, Indonesia. Jurnal Manusia dan Lingkungan. 23 (1), 42-48.

7. Chala B., Oechsner H., Latif S., Müller J. 2018. Biogas potential of coffee processing waste in Ethiopia. Sustainability, 10(8),1-14. https://doi. org/10.3390/ su10082678.

8. Climate Change Connection. 2016. $\mathrm{CO}_{2}$ Equivalent. Manitoba Eco-Network [Serial Online]. http;/climatechange connection.org/emissions/ co2-equivalent/.

9. Coltro L., Mourad A.L., de Oliveira P.P.L.V., Andrade J.P.B.O. 2012. Regional differences of coffee cultivation in Brazil. Coffee Science, 7(1), 31-41.http://taurus.unicamp.br/bitstream/ REPOSIP/90250/1/2-s2.0-84864363281.pdf

10. Cruz G, Crnkovic PM. 2015. Evaluation of the combustion process of coffee husk samples in a drop tube furnace (DTF). Engenharia Térmica (Thermal Engineering), 14(2):53-62. https://doi. org/10.13140/2.1.2139.8086

11. del Castillo M.D., Fernandez-Gomez B., MartinezSaez N., Iriondo-DeHond A., Mesa M.D. 2019, Coffee By-Products. In: Farah A., editor. Coffee: Production, Quality and Chemistry. Royal Society of Chemistry; Oxfordshire, UK: 2019.

12. Fatmawati, BPY Kurniawan, dan U Suryadi. 2018. Analisis Daya Saing Dan Strategi Pemasaran Kopi Bubuk Java Coffee. Jurnal Pertanian. 9 (2), 61-75.

13. Hareesh S.B., Jayarama, D’Souza M.V., Keshavayya J. 2017. The biochemical status of Robusta coffee (Coffea canephora) influenced by organic and integrated nutrient management practices. International Journal of Current Microbiology and Applied Sciences, 6(4), 232-239. https://doi. org/10.20546/ijcmas.2017.604.027

14. Harsono S.S, Prayoga, Tasliman, Maizirwan, Rida Robby, 2018, Effect of Holes System Designing for Low Energy Stove Using Coffee Husk Bio-Pellet as Solid Fuel, Journal of Advanced Research in Fluid Mechanics and Thermal Sciences, 2(5).

15. Harsono, S.S, Dilla, Maizirwan, 2019, coffee Husk Biopellet characteristics as Solid Fuel for combustion Stove, HSOA Journal of Environmental Science: Current Research, 1(1).
16. Ibnu M., Offermans A., Glasbergen P. 2018. Certification and farmer organisation: Indonesian smallholder perceptions of benefits.Bulletin of Indonesian economic studies, 54(3), 387-415. https://doi. org/10.1080/00074918.2018.150609

17. ISO 50001: 2018, Energy Management

18. Kiyingi I., Gwali S. 2012. Productivity and profitability of robusta coffee agroforestry systems in central Uganda. Uganda Journal of Agricultural Sciences, 13(1), 85-93. https://www.ajol.info/in- dex. php/ujas/article/view/126117/115645

19. Killian B., Rivera L., Soto M., Navichoc D. 2013. Carbon footprint across the coffee supply chain: The case of Costa Rican Coffee. Journal of Agricultural Science and Technology 3(3), 151-170. http://www.mag.go.cr/informacion/prog-nac-cafeCarbon-Footprint.pdf

20. KLH/ Kementerian Lingkungan Hidup. 2012. Pedoman Penyelenggaraan Inventarisasi Gas Rumah Kaca Nasional. Jakarta (ID): Kementerian Lingkungan Hidup (in Indonesian).

21. Mhilu C.F. 2014. Analysis of Energy Characteristics of Rice and Coffee Husks Blends. ISRN Chemical Engineering, 1-6. https://doi. org/10.1155/2014/196103

22. Murthy P.S., Madhava Naidu M. 2012. Sustainable management of coffee industry by-products and value addition - A review. Resour. Conserv. Recycl. 66, 45-58. doi: 10.1016/j.resconrec.2012.06.005.

23. Mussatto S.I., Machado E.M.S., Martins S., Teixeira J.A. Production, Composition, and Application of Coffee and Its Industrial Residues. Food Bioprocess Technol. 2011;4:661-672. doi: 10.1007/ s11947-011-0565-z.

24. Nugroho AW. 2014. Life Cycle Assessment (LCA) Industri Pengolahan Crude Palm Oil di PTPN V (Persero) Riau. Bogor:IPB.

25. Noponen M.R.A., Edwards-jones G., Haggar J.P, Soto G., Attarzadeh N., Healey J.R. 2012. Greenhouse gas emissions in coffee grown with differing input levels under conventional and organic management. Agriculture, Ecosystems \& Environment, 151, 6-15. Https://doi.org/10.1016/j. agee.2012.01.019

26. Panhuysen S., Pierrot J. 2014. Coffee Barometer 2014. Hivos, IUCN Nederland, Oxfam, Novib, Solidaridad, WWF.

27. Pehnelt, G., \& Vietze, C. 2012. Uncertainties About The GHG Emissions Saving of Repeseed Biodiesel (No. 2012, 039). Jena Economic Research Papers.

28. Rudragouda D.S., Mukharib K., Mote N., Gokavi R., Manjunath A.N., Babou C., Raghuramulu Y. 2017. Influence of micro irrigation and drip fertigation practices on yield and quality parameters of robusta coffee (Coffea canephora). International Journal of Current Microbiology and Applied Sci 
ences, 6(2), 701-706. https://doi.org/10.20546/ ijc- mas.2017.602.079.

29. Selvamurugan, M., Doraisamy, P., \& Maheswari, M. 2010. An Intregated Treatment Sytem For Coffee Processing Waste water using Anaerobic and Aerobic Process. Ecological Engineering. 36(12), 1686-1690.

30. Unique, 2019, Coffee Production In The Face Of Climate Change: Indonesia, https://www.sustaincoffee.org/assets/resources/Indonesia_CountryProfile_Climate_Coffee_6-11.pdf

31. USDA, 2019, Indonesia Coffee Annual Indonesia Coffee Annual Report 2019, https://apps.fas.usda. gov/newgainapi/api/report/downloadreportbyfilena me?filename $=$ Coffee $\% 20$ Annual_Jakarta_Indonesia_5-15-2019.pdf
32. Vera-Acevedo L.D., Vélez-Henao J.A., Marulanda-Grisales N. 2016. Assessment of the environmental impact of three types of fertilizers on the cultivation of coffee at the Las Delicias indigenous reservation (Cauca).

33. Wahyudi T., Jati M. 2012. Challenges of sustainable coffee certification in Indonesia. In Seminar on the Economic, Social and Environmental Impact of Certification on the Coffee Supply Chain, International Coffee Council 109th Session, London, United Kingdom 25th September 2012, pp. 1-14.

34. Wilson L., John G.R., Mhilu C.F., Yang W., Blasiak W. 2010. Coffee husks gasification us- ing high temperature air / steam agent. Fuel Processing Technology, 91(10), 1330-1337. https://doi. org/10.1016/j.fuproc.2010.05.003. 